\title{
Morphological method for the diagnosis of human adult type hypolactasia
}

\author{
L Maiuri, M Rossi, V Raia, F Paparo, S Coletta, F Mazzeo, A Breglia, S Auricchio
}

\begin{abstract}
The primary adult type hypolactasia is the most common form of genetically determined disaccharidase deficiency. This study examined a large and homogeneous population of the south of Italy: surgical biopsy specimens of proximal jejunum from 178 adult subjects have been assayed for disaccharidase activities; the expression of lactase protein and lactase activity has also been investigated on tissue sections by immunomorphological and enzymohistochemical techniques. Histograms of lactase to sucrase ratio were found to provide a useful distribution of the lactase activity; a lactase to sucrase ratio of 0.17 was found to show discrimination between tissues with persistence of high lactase activity and tissues with adult type hypolactasia. In all 28 subjects with persistent high lactase activity, a uniform distribution of lactase protein and lactase activity in all villus enterocytes was detected, whereas in all 150 subjects with adult type hypolactasia a variable number of villus enterocytes failed to express the lactase. Moreover in hypolactasic samples the lactase activity on tissue sections was constantly detected later than in samples with persistent high lactase activity. The absolute correlation between the immunohistochemical and enzymohistochemical features and the assessment of lactase activity in intestinal homogenates suggests that the morphological criteria are an alternative method for the diagnosis of adult type hypolactasia in human biopsy specimens from proximal small jejunum.

(Gut 1994; 35: 1042-1046)
\end{abstract}

Pediatrics

L Maiuri

M Rossi

V Raia

S Coletta

S Auricchio

and Department of Surgery, University

'Federico II' of Naples, Italy

F Mazzeo

Department of

Surgery, Ospedale

Cardarelli, Naples,

Italy

A Breglia

Correspondence to: Professor S Auricchio, Department of Pediatrics, University 'Federico II' of Naples, via S Pansini 5 , 80131 , Naples, Italy.

Accepted for publication 10 November 1993 birth. In a very high propor however, of the population in nor Europe, and many other milk drinking areas of the world, lactase activity persists into adult life. These two phenotypes, namely lactase hypolactasia) are genetically determined ${ }^{12}$ and are attributable to different alleles at one autosomal locus. The effect of the allele responsible for the persistence of lactase after childhood is dominant to that of the allele causing decline of lactase activity. ${ }^{3}$ Accordingly, lactase deficiency in adults is the recessive phenotype. By calculating the lactase/maltase or lactase/sucrase ratio $^{34}$ in small intestinal biopsy specimens, a trimodal distribution was found, pointing to a homozygous lactase deficient phenotype, and heterozygous or homozygous lactase persistent phenotypes. ${ }^{5-9}$

Recently it has been shown by immunohistochemical studies that in the proximal jejunum of subjects with persistent high lactase activity all the villus enterocytes express the lactase protein ${ }^{10}$ and lactase activity ${ }^{11}$ on the brush border whereas in adult hypolactasic subjects the lactase protein ${ }^{10}$ and lactase activity $^{11}$ were either absent or present on the brush border of only some villus enterocytes. Surface immunohistochemical and enzymohistochemical studies have shown that lactase positive enterocytes are uniformly present on the villus in the proximal small intestine of subjects with persistent high lactase activity, whereas in subjects with adult type hypolactasia scattered areas of enterocytes, which express lactase protein and lactase activity are randomly distributed on the villus wall. ${ }^{11}$

In adult mammals the expression of lactase protein and lactase activity showed an unexpected degree of complexity in the pattern of expression along the villus and along the proximal-distal axis of the small intestine: in the mid small intestine all enterocytes express the lactase protein ${ }^{12}$ and lactase activity ${ }^{11}$ whereas in the most proximal and distal parts the lactase is present only in patches of enterocytes interrupted by enterocytes containing no detectable protein ${ }^{12}$ or enzyme activity. ${ }^{11}$

We have studied a large white population from the Campania region in the south of Italy. We carried out disaccharidase assays and immunomorphological and enzymohistochemical analysis on the same specimens. Lactase persistent and lactase non-persistent phenotypes correlated closely with the morphological patterns. This suggested the possibility of making the diagnosis of adult type hypolactasia by morphological finding of enterocytes not containing lactase protein or lactase activity, or both in the proximal jejunum. persistent and lactase non-persistent (adult

\section{Methods}

\section{HUMAN INTESTINAL SAMPLES}

Proximal intestinal jejunal specimens were taken from 178 adult patients who were receiving intestinal resection. Informed consent was obtained from all patients. All the subjects were white, and were born in the south of Italy. They were aged from 22 to 78 years. The 
patients needed surgery because of gastric cancer, duodenal or gastric ulcer, biliary tract diseases, pancreatitis or gastric lymphoma. The patients were not given any cytostatic or antibiotic drugs - that is, neomicin, before surgery. The samples were taken about $5 \mathrm{~cm}$ distal to the ligament of Treitz and far from the intestinal lesion; in all subjects they were histologically normal. These specimens were divided, half for histological studies and half for enzyme assays.

\section{ASSAY OF ENZYME ACTIVITIES}

Samples were homogenised at $2 \%$ concentration in $2 \mathrm{mmol} / \mathrm{l} \mathrm{TRIS} / \mathrm{HCl}$ and $50 \mathrm{mmol} / \mathrm{l}$ mannitol ( $\mathrm{pH} 7 \cdot 1)$. Sucrase and maltase activities were assayed according to the method of Auricchio et al. ${ }^{13}$ The lactase activity was assayed in the presence of $p$-chloromercuribenzoate. ${ }^{14}$ For all samples with low disaccharidase activities, $\mathrm{Zn}(\mathrm{OH})_{2}$ deproteinisation was used ${ }^{15}$; this procedure eliminates any interference with the glucose oxidase assay, which is otherwise produced by the high concentration of the intestinal homogenate needed when determining low disaccharidase activities. $^{16}$ All chemical reagents were obtained from Sigma Chemical Co, St Louis, MO, USA.

\section{MONOCLONAL ANTIBODIES AGAINST HUMAN \\ LACTASE}

Eight monoclonal antibodies against human lactase were used in this study. The methods and the characteristics of these antibodies, kindly donated by Dr Dallas Swallow (London) are reported in Green et al ${ }^{17}$ and in our previous paper. ${ }^{10}$

MONOCLONAL ANTIBODIES AGAINST HUMAN SUCRASE AND HUMAN ISOMALTASE

Antibodies $\mathrm{CaCo}$ 3/73 and HSI-9, kindly

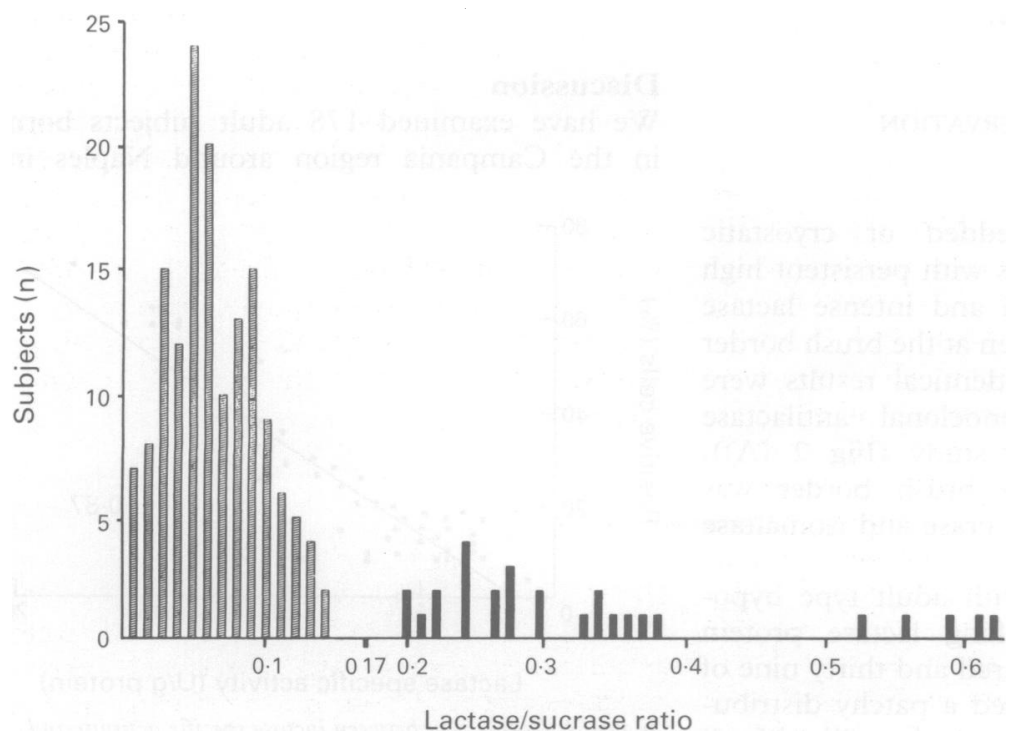

Figure 1: Distribution of the lactase to sucrase ratio in the proximal small intestine of 178 Neapolitan adults. Filled bars = subjects with persistent high lactase activity; hatched bars $=$ hypolactasic subjects. donated by Dr Quaroni were prepared as previously described. ${ }^{18} 19$

\section{HISTOLOGICAL STUDIES}

\section{Immunohistochemistry}

One part of the tissue was fixed in $4 \%$ formol acetate solution and embedded in paraffin wax according to routine histological procedure; another part was frozen immediately and kept at $-80^{\circ} \mathrm{C}$ until used. Five $\mu \mathrm{m}$ sections were incubated with mouse monoclonal antibodies against human lactase, human sucrase, or human isomaltase, as previously described ${ }^{10}$ $\left(1: 20-1: 50\right.$, overnight at $\left.4^{\circ} \mathrm{C}\right)$ followed by biotinylated rabbit Ig directed against mouse Ig (Dako, Copenhagen, Denmark) (1:200 for one hour) and the streptavidin peroxidase complex (Dako) (1:300 for one hour). The sections were previously incubated with $0.004 \%$ protease XXIV (Sigma) to enhance their immunoreactivity and also pretreated with $3 \%$ normal goat serum to prevent nonspecific binding. Ten sections of each specimen were individually tested with all eight monoclonal antilactase antibodies. Control staining reactions included replacement of the antilactase antibodies with (a) phosphate buffer, (b) monoclonal antibody with another specificity but with the same immunoglobulin isotype.

\section{Enzymohistochemistry}

One part of the tissue samples, immediately frozen in liquid nitrogen, was cut with a cold microtome into $10 \mu \mathrm{m}$ thick sections. The sections were transferred to slides at room temperature on which they thawed immediately. They were then dried at room temperature for 30 minutes. The experiments were carried out according to Lojda and $\mathrm{Kraml}^{20}$ by using $5 \mathrm{Br}-4 \mathrm{Cl}-3$ indolyl- $\beta$-Dfucoside (Sigma) as a substrate, which gives a blue reaction product.

In 10 tissues with persistent high lactase activity and in 35 hypolactasic samples, the lactase activity in villus attached enterocytes were also measured in a quantitative way according to Gutschmidt $e t a l^{21}$ as previously described. ${ }^{22}$

\section{STATISTICAL METHODS}

The distribution of each variable (lactase, sucrase, maltase, lactase/sucrase ratio) was examined by the EXAMINE procedure of SPSS Pc + for the distribution.

\section{Results}

DISACCHARIDASE ACTIVITIES

Traditionally subjects were classified as hypolactasic or lactase persistent by determining the ratio of sucrase to lactase activity. A ratio of about 7.5 provided a convenient benchmark to discriminate subjects with a genetic hypolactasia from those with persistent high lactase 

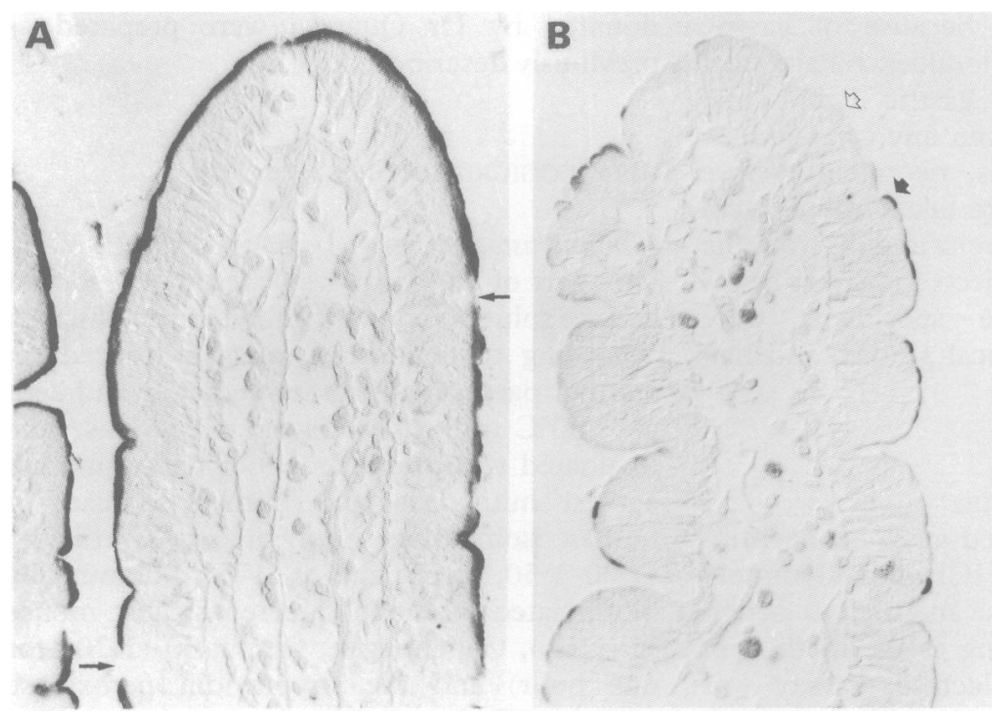

Figure 2: Lactase immunoreactivity in the proximal small intestine of adult humans. (A) Expression of lactase protein in a subject with persistent high lactase activity. The lactase protein is uniformly distributed on the brush border of all villus enterocytes; the only interruptions of staining correspond to the goblet cells (arrow). (Monoclonal antibody mlac 1; paraffin wax embedded tissue, immunoperoxidase technique, original magnification X 470); (B) Expression of lactase protein in a subject with adult type hypolactasia. The lactase protein is patchily distributed. Some villus enterocytes express the lactase protein (arrow). whereas the other enterocytes fail to show any immunoreactivity (arrow head). (Monoclonal antibody mlac 1; paraffin wax embedded tissue, immunoperoxidase technique, original magnification $\times 470)$.

activity in necropsy samples of the lower jejunum $^{8}$ and also in the surgical biopsy samples of proximal jejunum in our study population. ${ }^{10}$

In our extended survey, however, which contains mainly hypolactasic subjects, many of whom have very low lactase activities, histograms of lactase/sucrase ratio are more useful to discriminate the different groups of subjects (Kolgoroff-Smirnoff not significant). Twenty eight subjects had persistent high lactase activity with a lactase/sucrase ratio $>0 \cdot 20$, whereas 150 subjects had adult type hypolactasia with lactase/sucrase ratio $<0 \cdot 14$; therefore a lactase/sucrase ratio of 0.17 can be used to discriminate the two groups of subjects (Fig 1).

In all subjects sucrase and maltase activities were within normal range. ${ }^{23}$

\section{LIGHT MICROSCOPIC OBSERVATION}

\section{Immunohistochemistry}

In paraffin wax embedded or cryostatic sections from all subjects with persistent high lactase activity, uniform and intense lactase immunoreactivity was seen at the brush border of villus enterocytes. Identical results were obtained with all monoclonal antilactase antibodies used in this study (Fig 2 (A)). Intense staining of the brush border was similarly seen with the sucrase and isomaltase specific antibodies.

In all 150 subjects with adult type hypolactasia enterocytes lacking lactase protein were present. One hundred and thirty nine of these 150 subjects showed a patchy distribution of immunoreactivity on the villi with all the monoclonal antilactase antibodies. This mosaic pattern was characterised by the presence of enterocytes with intensely stained brush border surrounded by mostly negative cells; enterocytes with faint staining of the brush border were also seen (Fig 2 (B)). In 50 of these 139 patients with a hypolactasia we counted the number of positive cells: the percentage of lactase positive enterocytes varied between $4 \%$ and $71.6 \%$ of total absorptive cells (mean (SD) $24.56(12.4)$ ). A significant correlation between overall lactase activity in the mucosa and the percentage of enterocytes showing staining of the brush border was present $(r=0.9)$ (Fig 3). In all the hypolactasic samples in vitro biosynthetic studies have shown reduced synthesis of the lactase protein, as previously reported. ${ }^{24}$ In contrast with the results obtained with the anti-lactase antibodies, uniform and intense staining of the brush border of all villus absorptive cells was found in the same subjects with sucrase and isomaltase specific antibodies.

Eleven of 150 subjects with adult type hypolactasia showed complete lack of staining with all the antibodies to lactase with intense and homogeneous brush border staining with the anti-sucrase and anti-isomaltase antibodies.

\section{ENZYMOHISTOCHEMISTRY}

In all subjects with persistent high lactase activity the lactase activity was detected in all villus enterocytes (Fig 4 (A)). By contrast, in all the subjects tested with adult type hypolactasia the lactase activity was patchily expressed (Fig 4 (B)) and it was present in the same villus enterocytes expressing the lactase protein.

In tissues with persistent high lactase activity, the lactase activity is detected in all villus enterocytes after only five minutes of incubation with the substrate; by contrast, the lactase activity is still undetectable after 15 minutes of incubation in hypolactasic samples; moreover, after 120 minutes of incubation the staining is much stronger in persistent than in hypolactasic tissues (Fig 5), thus confirming our previous findings. ${ }^{22}$

\section{Discussion}

We have examined 178 adult subjects born in the Campania region around Naples in

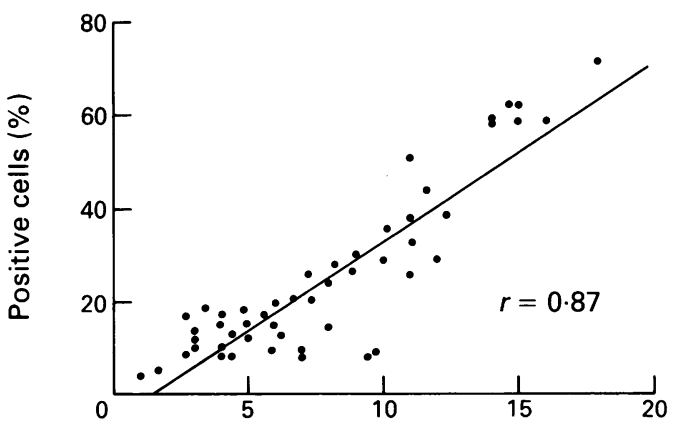

Lactase specific activity (U/g protein)

Figure 3: Correlation between lactase specific activity and percentage of lactase containing enterocytes in small intestinal biopsy specimens of proximal jejunum from 50 Neapolitan adults. 

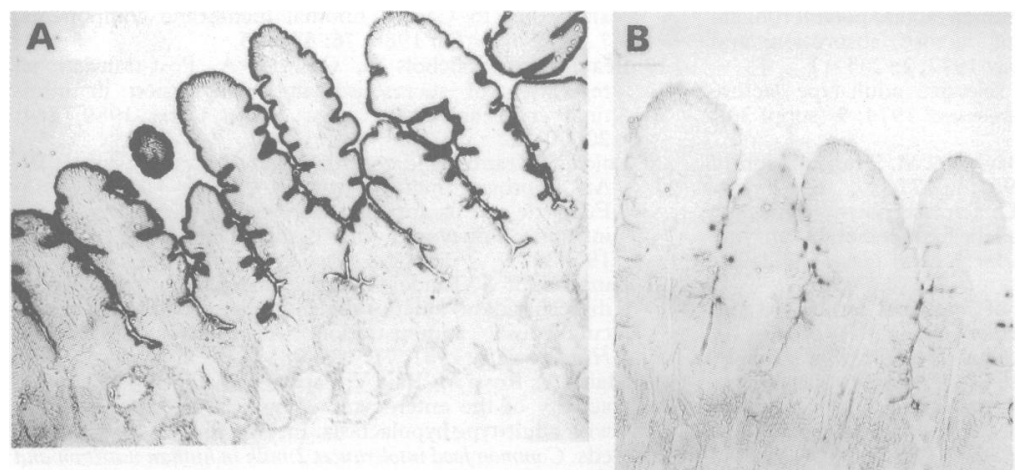

Figure 4: Expression and distribution of lactase activity by villus enterocytes of proximal small intestine of adult humans. $(A)$ : Subject with persistent high lactase activity - an intense staining is evident on the brush border of all villus enterocytes. The crypt enterocytes are negative (enzymohistochemistry, original magnification $\times 100) ;(B)$ : subject with adult type hypolactasia - the staining is evident on the brush border of some villus enterocytes; the other enterocytes are negative (enzymohistochemistry, original magnification $\times 100)$. enterocytes exist in the more distal parts of the small intestine. The diagnostic endoscopic or peroral biopsies are performed around the Treitz region, however, in the same region where the tissue specimens used in this study were taken from. The test proposed for the diagnosis of adult type hypolactasia is performed on paraffin wax embedded or cryostatic samples, which are generally used as well for other morphological purposes. Moreover, in hypolactasic tissues, the lactase activity is also still undetectable after 15 minutes of incubation with the substrate, whereas in tissues with persistent high lactase activity it is detected after only five minutes of incubation; therefore, the absence of staining after five minutes of incubation of frozen tissue sections with the substrate, is a sufficient criterium to make diagnosis of adult type hypolactasia.

Only in a few hypolactasic subjects (11 of 150 subjects) was the lactase absent from all villus enterocytes; probably because a few positive enterocytes are present in closely adjacent jejunal regions.

Our findings are interesting not only as an alternative diagnostic procedure, but also for understanding the mechanisms that underlie the adult type hypolactasia. The presence of enterocytes without lactase activity is one of the mechanisms controlling the intestinal lactase activity in the proximal small intestine of hypolactasic humans. The number of positive enterocytes was in fact related to the lactase activity in these subjects. This is in agreement with the finding that most biopsy specimens taken from the proximal jejunum of hypolactasic adults show reduced synthesis of lactase protein in vitro and low levels of lactase mRNA. ${ }^{26-28}$ Moreover, in hypolactasic tissues the quantitative enzymocytochemical assessment of lactase activity in villus attached enterocytes shows that the enterocytes of hypolactasic tissues also have less lactase activity than enterocytes of persistent tissues. ${ }^{22}$ This suggests that in adult type hypolactasia the lactase protein is most probably present in reduced amounts or is less active.

Mechanisms controlling lactase activity in villus enterocytes in adult type hypolactasia are being investigated in our laboratory by in vitro biosynthetic studies and by in situ hybridisation.

The authors thank Dr Dallas Swallow of the MRC, Human Biochemical Genetics Unit, University College London, for the gift of the monoclonal anti-lactase antibodies and Dr Luigi Greco of the Department of Pediatrics, University 'Federico II' of Naples, Italy, for the statistical analysis of the data.

This paper is dedicated to Professor Salvatore Auricchio on the occasion of his 60 th birthday.

1 Auricchio S, Rubino A, Landolt M, Semenza G, Prader A. Isolated intestinal lactase deficiency in the adult. Lancet 1963; ii: 324-6.

2 Semenza G, Auricchio S. Small intestinal disaccharidases. In: Scriver CR, Beaudet AL, Sly WS, Valle D, Stanbury JB, Wyngaarden JB, et al, eds. The metabolic basis of inherited diseases. 6th ed. New York: McGraw-Hill, 1989: ited diseases.

3 Ellestead-Sayed J, Haiworth JC, Hildes JA. Disaccharidase consumption and malabsorption in Canadian Indians. Am $\mathcal{F}$ Clin Nutr 1977; 30: 698-703.

4 Ellestead-Sayed JJ, Haiworth JC, Hildes JA. Disaccharidase malabsorption and dietary patterns in two Canadian Eskimo communities. Am 7 Clin Nutr 1978; 31: 1473-8.
Figure 5: Quantitative assessment of lactase activity in villus enterocytes of 10 subjects with persistent high lactase activity and 35 subjects with adult type hypolactasia. 
5 Flatz G, Rotthauve HW. The human lactase polymorphism: physiology and genetics of lactose absorption and malabsorption. Prog Med Genet 1977; 2: 205-11.

6 Sahi T. The inheritance of selective adult-type lactose malabsorption. Scand $\mathcal{f}$ Gastroenterol 1974; 9 (suppl 30): 1-23.

7 Rosenzweig NS, Huang SS, Bayless TM. Transmission of lactose intolerance. Lancet 1967; ii: 777.

8 Ho MW, Povey S, Swallow D. Lactase polymorphism in British natives: estimating allele frequencies by enzyme assays in autopsy samples. Am f Hum Genet 1982; 34: $650-7$.

9 Flatz G. Gene dosage effect of intestinal lactase activity demonstrated in vivo. Am ₹ Hum Genet 1984; 36: 306-10.

10 Maiuri L, Raia V, Potter J, Swallow D, Ho MW, Fiocca R, et al. Mosaic pattern of lactase expression by villus enterocytes in human adult-type hypolactasia. Gastroenterology 1991; 100: 359-69.

11 Maiuri L, Rossi M, Raia V, Paparo F, Garipoli V, Auricchio $S$. Surface staining on the villus of lactase protein and lactase activity in adult-type hypolactasia. Gastroenterology 1993; 105: 708-14.

12 Maiuri L, Rossi M, Raia V, D'Auria S, Swallow D, Quaroni $A$, et al. Patchy expression of lactase protein in adult rabbit and rat intestine. Gastroenterology 1992; 103: 1739-46.

13 Auricchio S, Rubino A, Tosi R, Semenza G, Kistler H, Prader A. Disaccharidase activities in human intestinal Prader A. Disaccharidase activities in huma

14 Asp NG, Dahlqvist A. Human small intestinal B-galactosidases. Specific assay of three different enzymes. Anal Biochem 1972; 47: 527-38.

15 Sebastio G, Huzinker W, Ballabio A, Auricchio S, Semenza $G$. On the primary site of control in the spontaneous development of small intestinal sucrase-isomaltase after birth. FEBS Lett 1986; 208: 460-4.

16 Ciccimarra F, Starace E, Vegnente A. Osservazioni sul metodo di dosaggio delle attivita' disaccaridasiche nella mucosa intestinale umana. Boll Soc Ital Bio Sper 1968; 45: 336-9.

17 Green FR, Greenwell P, Dickson L, Griffiths B, Noades J, Swallow DM. Expression of the ABH, Lewis, and related antigens on the glycoproteins of the human jejunal brush antigens on the glycoproteins of the human jejunal brush border. In: J R Harris, ed. I

18 Quaroni A. Crypt cell antigen expression in human tumor colonic cell lines. Analysis with a panel of monoclonal antibodies to Caco-2 luminal membrane components. f Natl Cancer Inst 1986; 76: 571-85.

19 Beaulieu JF, Nichols B, Quaroni A. Post-translational regulation of sucrase-isomaltase expression in intestinal crypt and villus cells. F Biol Chem 1989; 264: 20000-11.

20 Lojda Z, Kraml J. Indigogenic methods for glycosidases III. An improved method with 4-Cl-5-Br-3-Indolyl- $\beta-\mathrm{D}$ Fucoside and its application in studies of enzymes in the intestine, kidney and other tissues. Histochemie 1971; 25 intestine,

21 Gutschmidt S, Emde C. Early changes in brush border disaccharidase kinetics in rat jejunum following subcutaneous administration of tetraiodothyronine. Histochemistry 1981; 71: 189-98.

22 Maiuri L, Rossi M, Raia V, Paparo F, Auricchio S. Lactase activity of the enterocytes of human proximal jejunum with adult-type hypolactasia. In: Auricchio S, Semenza G, eds. Common food intolerances 2:milk in human nutrition and adult-type hypolaciasia. Basle: Dyn Nutr Res 3, Karger, 1993: 161-7.

23 Haemmerli U, Kistler HJ, Hamman T, Marthaler T, Semenza G, Auricchio S. Acquired milk intolerance in the adult caused by lactose malabsorption due to a selective deficiency of intestinal lactase activity. $\mathrm{Am} \mathfrak{\exists} \mathrm{Med} 1965$; 38: 7-15.

24 Rossi M, Maiuri L, Fusco MI, Danielsen EM, Auricchio S. The human adult-type hypolactasia is a heterogeneous condition in in vitro biosynthetic studies. In: Auricchio S, condition in in vitro biosynthetic studies. In: Auricchio $S$, Semenza G, eds. Common food intolerances 2: milk in human nutrition and adult-type hypo

25 Rinaldi E, Albini L, Costagliola C, De Rosa G, Auricchio $\mathrm{G}$, De Vizia B, et al. High frequency of lactose absorbers among adults with idiopathic senile and presenile cataract in a population with a high prevalence of primary adult lactose malabsorption. Lancet 1984; i: 355-7.

26 Sebastio G, Villa M, Sartorio R, Guzzetta V, Poggi V, Auricchio $S$, et al. The control of lactase in human adult-type hypolactasia and in weaning rabbits and rats. Am f Hum Genet 1989; 45: 489-97.

27 Witte JM, Lloyd M, Lorenzson V, Korsmio H, Olsen W. The biosynthetic basis of adult lactase deficiency. f Clin Invest 1990; 86: 1338

28 Lloyd M, Mevissen G, Fisher M, Olsen W, Goodspeed D, Genini $M$, et al. Regulation of intestinal lactase in adult hypolactasia. F Clin Invest 1992; 89: 524-9. 